\title{
Dating and Digging Stratified Archaeology in Circumpolar North America: A View from Nunalleq, Southwestern Alaska
}

\author{
Paul M. Ledger, ${ }^{1,2}$ Véronique Forbes, ${ }^{1}$ Edouard Masson-MacLean ${ }^{1}$ and Richard A. Knecht ${ }^{1}$
}

(Received 11 March 2016; accepted in revised form 7 July 2016)

\begin{abstract}
Through the case study of the Thule-era village site of Nunalleq (GDN-248), this paper presents ${ }^{14} \mathrm{C}$ dating results and perspectives on the issues associated with radiocarbon dating stratified archaeological sites in circumpolar North America. The objective was to investigate relative variation in the ${ }^{14} \mathrm{C}$ age of ecofacts with the aim of establishing a hierarchy of dating suitability for Nunalleq that could more widely inform ${ }^{14} \mathrm{C}$ sample selection on archaeological sites across the North American sub-Arctic and Arctic and Greenland. Owing to the complexities associated with interpreting and establishing the relative chronology of the deeply stratified sod deposits at Nunalleq, we adopted open-area excavation and single-context recording methods. This approach, we suggest, allowed us to eliminate stratigraphic complexity as a source of variation in ${ }^{14} \mathrm{C}$ measurements and to assess the taphonomic issues associated with dating different ecofacts. In total, 16 samples were submitted for dating, comprising two sets of eight different ecofacts, one from each of two stratigraphically contemporary but spatially discrete contexts. In most instances, the ${ }^{14} \mathrm{C}$ ages of ecofacts were statistically indistinguishable between the two contexts and support the relative chronological relationships established by excavation. Only Elymus arenarius (grass) manufactures and Heleomyzidae (fly) puparia produced different ages in the two contexts, variations that suggest that these items are unreliable dating materials. As noted in previous studies, Phoca sp. (seal) and Oncorhynchus sp. (salmon) bone collagen demonstrated a strong marine reservoir effect (c. $700{ }^{14} \mathrm{C}$ yr.). Picea sp. (wood chips) were marginally older than seeds from edible berries (Rubus chamaemorus and Empetrum nigrum) and caribou (Rangifer tarandus) bone collagen, which provided the most consistent ages.
\end{abstract}

Key words: radiocarbon dating; single-context recording; Arctic; Alaska; Thule; archaeology

RÉSUMÉ. Par le biais d'une étude portant sur le village de Nunalleq (GDN-248), appartenant à l'ère thuléenne, cet article présente les résultats de datations par le carbone 14 ainsi que les problèmes liés à la datation des sites archéologiques stratifiés situés dans la zone circumpolaire de l'Amérique du Nord. L'objectif consistait à examiner les variations relatives entre les âges C14 obtenus pour différents types d'écofacts, dans le but d'établir une hiérarchie pour Nunalleq qui pourrait plus largement informer la sélection de matériel à dater sur les sites archéologiques à l'échelle des régions subarctiques et arctiques de l'Amérique du Nord ainsi que du Groenland. Afin de faciliter l'interprétation et l'établissement d'une chronologie relative pour les dépôts de tourbe profondément stratifiés à Nunalleq, nous avons effectué des fouilles archéologiques à aire ouverte et adopté le « single context recording » comme système d'enregistrement. Nous suggérons que cela nous a permis d'éliminer la complexité stratigraphique comme source de variation dans les mesures de l'activité radiologique du carbone 14 et d'examiner les processus taphonomiques liés à la datation de différents types d'écofacts. Au total, 16 échantillons, comprenant deux séries de huit types d'écofacts différents provenant d'unités archéologiques stratigraphiquement contemporaines, mais spatialement distinctes, ont été soumis pour datation par le radiocarbone. Dans la plupart des cas, les datations obtenues pour chaque type d'écofact sont statistiquement indiscernables pour les deux contextes, soutenant ainsi les relations concernant la chronologie relative établie lors des fouilles archéologiques. Seuls les objets faits avec Elymus arenarius (herbe) et les puparia Heleomyzidae (mouche) ont produit des âges qui diffèrent entre les contextes, ce qui suggère que ces types d'écofacts ne sont pas recommandables comme matériaux à dater. Comme anticipé, le collagène osseux de Phocas sp. (phoque) et Oncorhynchus sp. (saumon) démontre un fort effet 'réservoir marin' (environ 700 ans $\mathrm{C}^{14}$ ). Les copeaux de bois (Picea sp.) sont marginalement plus âgés que les graines de baies comestibles (Rubus chamaemorus et Empetrum nigrum) et le collagène osseux de caribou (Rangifer tarandus), qui ont produit les datations les plus cohérentes.

Mots clés : datation par le carbone 14; single context recording; Arctique; Alaska; Thulé, archéologie

Révisé pour la revue Arctic par Nicole Giguère.

(c) (i) This work is licensed under a Creative Commons Attribution 4.0 International License

${ }^{1}$ Department of Archaeology, School of Geosciences, University of Aberdeen, Elphinstone Road, Aberdeen AB24 3UF, United Kingdom

${ }^{2}$ Corresponding author: p.ledger@abdn.ac.uk

(C) The Arctic Institute of North America 


\section{INTRODUCTION}

Accurate and robust radiocarbon chronologies from Thuleera and antecedent archaeological sites in the North American Arctic and sub-Arctic (from Alaska in the west to Greenland in the east) are rare (McGhee, 2000). Despite the excellent preservation potential for organic materials in the permafrost soils of circumpolar regions, researchers have often struggled with constructing what they consider to be accurate radiocarbon-based chronologies (e.g., Gerlach and Mason, 1992; Park, 1994; Grønnow and Jensen, 2003; Betts, 2008; McGhee, 2009; Anstey et al., 2016), and the site of Nunalleq, the subject of this paper, is no exception. The difficulties are much discussed, and numerous authors have contributed to the debate (e.g., Arundale, 1981; Morrison, 1989; Gerlach and Mason, 1992; Park, 1994; Dumond and Griffin, 2002; West, 2011; Anderson and Freeburg, 2013; Ramsden and Rankin, 2013). A primary cause of dating issues - although unrelated to radiocarbon dating itself-stems from the cold and dry nature of northern environments, which results in limited biological activity and in many places almost non-existent soil formation (McGhee, 1996). This general dearth of soil accumulation results in a widespread, although not complete, absence of stratified archaeology in the North. Stratigraphy, and the relative chronological information contained within, is fundamental to dating in archaeology. It provides the means to differentiate occupation episodes, estimate their duration, and perhaps most importantly, assess the reliability of other chronological information such as ${ }^{14} \mathrm{C}$ data. Where there is little soil accumulation, traces of multiple and chronologically distinct cultural episodes may form only a thin archaeological deposit, giving the impression of a single short-term occupation. However, ${ }^{14} \mathrm{C}$ dates from such settings often reveal palimpsests of multiple cultural events, and there is no way of establishing the association between different artefacts or features and their absolute age (e.g., Grønnow and Jensen, 2003). The widespread absence of stratigraphy in the North has therefore deprived archaeologists of a powerful route to building robust chronologies for the history of Arctic peoples (c.f. Giddings, 1967).

The major problems associated with radiocarbon dating can be broadly summarized as taphonomic factors. Preeminent in this list is the marine reservoir effect (McGhee and Tuck, 1976; Park, 1994). Marine resources were central to traditional lifeways in circumpolar North America, and products of the sea are abundant on archaeological sites (Dumond, 1987; Woollett et al., 2000; Grønnow and Jensen, 2003). Consequently, a large proportion of the organic remains available for radiocarbon dating are either marine in nature or have come into contact with marine resources (Morrison, 1989; Park, 1994; Gulløv, 1997). In fact, the abundance of marine products and their associated oils has anecdotally been implicated as an auxiliary factor contributing to the difficulties experienced in radiocarbon dating Arctic sites. It has been suggested that seal oils permeate everything to such an extent that the radiocarbon ages of terrestrial materials are significantly skewed (Park, 1994). Although this idea is widespread in the literature (e.g., Morrison, 1989; Park, 1994; McGhee, 2000; Anderson and Freeburg, 2013), the marine mammal oil effect has yet to be demonstrated empirically.

A further, somewhat diffuse, phenomenon is something that Park (1994:31) termed the "terrestrial reservoir effect." This label has been used to group diverse situations in which ${ }^{14} \mathrm{C}$ assays on materials that are exclusively derived from the terrestrial biosphere-i.e., terrestrial plants or herbivore bone collagen - produce what are deemed to be aberrant ages (Morrison, 1989; Park, 1994). For example, terrestrial (typically woody) plant macrofossils that have been interpreted as being contemporary sometimes provide very different ${ }^{14} \mathrm{C}$ ages (e.g., McGhee and Tuck, 1976; Schledermann and McCullough, 1980; Jensen, J.F., 2006). Similar problems have also been noted in Arctic lake sediments, where differing parts of terrestrial plants (e.g., wood, leaves, and seeds) recovered from the same depth in a lake can have sharply differing ${ }^{14} \mathrm{C}$ activities (Mann et al., 2002; Oswald et al., 2005). Varying reasons for this anomaly have been advanced. These include 1) slow organic decay in the Arctic that results in longer residence times in permafrost soils for "old" carbon, which then becomes incorporated into plant and herbivore tissues; 2) differential ${ }^{14} \mathrm{C}$ fractionation between plant species (Morrison, 1989; Park, 1994), although modern radiocarbon laboratories correct for this problem (Walker, 2005); and 3) taphonomic issues that result in certain macrofossils having an "inbuilt" age (sensu McFadgen, 1982; i.e., the time differential between the age of death and the date of deposition).

A less explicitly discussed problem (although see Morrison, 1989) may arise as a result of the challenging logistics associated with fieldwork in Arctic regions. Sites are often difficult and expensive to access, resulting in small-scale investigations by a limited number of excavators or non-specialists working under time pressure. Consequently, when excavating, Arctic researchers have tended to adopt the planum or Wheeler box-grid methods or hybrids of the two (e.g., Knecht and Jordan, 1985; Sutherland, 2009; although see Savelle and Habu, 2004; Hodgetts et al., 2015 for exceptions). Indeed, the initial rescue excavations at Nunalleq were conducted in this manner. The defining feature of these methods is digging in a series of independent grid squares. In each square, the excavator records changes (with reference to stratigraphic sections) at either arbitrary or natural levels, thereby establishing a relative chronological sequence for that square. The associations of deposits excavated in different squares are then inferred between these islands of information. Both approaches afford lowcost, rapid excavation of large areas (Renfrew and Bahn, 2004); however, they can result in imprecise appreciation of deep and complex site stratigraphy and a tendency to summarize it (Branch et al., 2005). Relative chronologies can be established with certainty for both deposits and artefacts and ecofacts within a single square, but temporal relationships between squares can potentially be misinterpreted. 
If radiocarbon dates are then procured on organic materials drawn from multiple squares, this may pose interpretational problems. Indeed, the initial radiocarbon rangefinder data from Nunalleq, which contained age/depth inconsistencies (discussed below), stands as an example. Strong understanding of the sequence of events that led to the formation of archaeological deposits is essential for producing both relative and radiometric-based chronologies of a site (Bayliss, 2009). Without this understanding, the taphonomic issues identified above, which are known to result in erroneous ${ }^{14} \mathrm{C}$ ages, can become conflated with imprecision in stratigraphic interpretation to the point that these two sources of error are seemingly inseparable. Therefore, in order to understand the cause of variations in the ${ }^{14} \mathrm{C}$ age of different dating materials, it is essential to be certain that relative chronological differences are not the source of age variation.

A valuable method for evaluating the taphonomic issues associated with dating different ecofacts and artefacts is to undertake multiple radiocarbon measurements on materials of contemporary age. Unfortunately, because of a general or presumed paucity of ecofactual remains (e.g., Jensen, A.M., 2006) on Arctic archaeological sites, few investigations of this nature have been undertaken. Where such work does exist, it has tended to focus on elucidating the strength of the marine reservoir effect (e.g., Dumond and Griffin, 2002). The purpose of this paper is to use the Thule-era site of Nunalleq, which contains a plethora of different ecofactual remains, to expand the scope of such studies. Using open-area excavation and single-context recording, we identified two spatially discrete yet contemporary house floors that could be used to investigate the ${ }^{14} \mathrm{C}$ age variation of a series of common and rarely examined ecofactual remains. Using these data, we aim to (1) test the accuracy of single-context recording as a means of establishing relative temporal relationships of deposits on Arctic archaeological sites; 2 ) use ${ }^{14} \mathrm{C}$ data to investigate the taphonomy of ecofactual remains present within sod dwellings and determine which ecofact(s) provide the most reliable ${ }^{14} \mathrm{C}$ ages in such situations; and 3) establish a hierarchy of suitability for the dating of ecofacts from Nunalleq that can inform dating decisions on other archaeological sites in the New World Arctic.

\section{Nunalleq}

Nunalleq (GDN-248) is located close to the Yup'ik

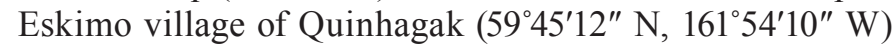
on the coast of the Bering Sea in southwestern Alaska (Fig. 1). The site is set within the organic-rich delta of the Kanektok and Arolik Rivers, which form part of the wider braided system of the Yukon-Kuskokwim (Y-K) Delta, a landscape characterized by flat, low-lying treeless tundra dotted with lakes and underlain by discontinuous permafrost (Alaska Center for Conservation Science, 2016). The archaeological site was discovered in 2009 by residents of Quinhagak, who found a series of artefacts on the beach

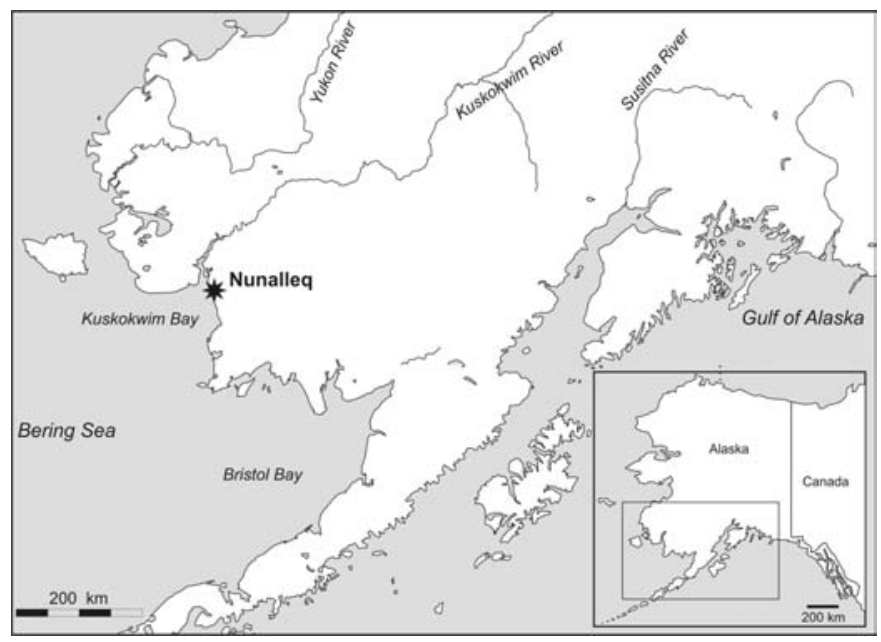

FIG. 1. Location of Nunalleq within southwestern Alaska.

near the site. Rescue excavations of the western part of the site using the planum method were initiated that year in conjunction with the local community and continued in 2010. The result was the discovery of the remains of a multiphase village with numerous house floor layers that yielded tens of thousands of in situ lithics, pottery fragments, and artefacts of wood and grass. In addition, there were exceptionally well preserved ecofacts, including bone from terrestrial and marine animals, diverse plant remains, insects, fur, and human hair (Britton et al., 2013; Forbes et al., 2015). A suite of rangefinder dates on materials excavated between 2009 and 2012 returned ages from 182 \pm 37 BP to $650 \pm 40$ BP (Table 1), implying a Thule-era occupation of three to four centuries (Britton et al., 2013). A simple Bayesian model combining these data suggested occupation dating from cal. AD 1310 to AD 1420, with abandonment somewhere between AD 1650 and AD 1750 (Britton et al., in press), which is consistent with the absence of Euromerican material culture at the site. Although the organic remains to be dated were selected exclusively from short-lived terrestrial species, the resulting data presented some inconsistencies. Contrary to expectations, the youngest ${ }^{14} \mathrm{C}$ age was returned on material excavated from one of the deepest levels of the site, and materials from the same level but different squares produced significantly varying ages (Fig. 2). In one instance, three assays from the same level and square (Square 1, Level 4) returned a series of statistically different dates (Table 1). A further issue was apparent in Square 2, where the ${ }^{14} \mathrm{C}$ assay from level 3 predated the assay from level 4. Importantly, Squares 1 and 2 furnished the oldest radiocarbon dates from the site and suggest that the beginning of occupation is unlikely to have pre-dated AD 1450.

Owing to a growing appreciation of the complexity of the stratigraphy (borne out in the inconsistencies of ${ }^{14} \mathrm{C}$ rangefinders) at Nunalleq and the desire to undertake systematic environmental sampling, we decided to adopt openarea excavation and single-context recording from 2013 on. At least three different occupation phases are evident, the 
TABLE 1. Radiocarbon rangefinder dates from samples excavated during the rescue excavations in 2009 and 2010. NR = not recorded.

\begin{tabular}{|c|c|c|c|c|c|c|}
\hline Lab code & Square & Level & Material dated & ${ }^{14} \mathrm{C}$ yr BP $( \pm 1 \sigma)$ & $\mathrm{AD}( \pm 2 \sigma)$ & $\delta^{13} \mathrm{C}(\%)$ \\
\hline SUERC-54993 & 90 & 5 & Rangifer tarandus & $182 \pm 37$ & $1648-1950$ & -17.80 \\
\hline Beta-297108 & 6 & 4 & Plant material & $230 \pm 40$ & $1521-1950$ & -26.40 \\
\hline SUERC-53011 & 5 & 4 & Rangifer tarandus & $264 \pm 28$ & $1520-1799$ & -17.70 \\
\hline Beta-308745 & 1 & 4 & Rubus chamaemorus & $290 \pm 30$ & $1492-1663$ & -27.00 \\
\hline Beta-308744 & 15 & 3 & Plant material & $290 \pm 30$ & $1492-1663$ & -26.20 \\
\hline SUERC-53015 & 6 & 4 & Rangifer tarandus & $299 \pm 30$ & $1489-1655$ & -18.00 \\
\hline SUERC-53017 & 11 & 3 & Rangifer tarandus & $362 \pm 30$ & $1450-1635$ & -17.60 \\
\hline SUERC-53018 & 12 & 3 & Rangifer tarandus & $389 \pm 30$ & $1441-1631$ & -17.80 \\
\hline SUERC-53016 & 9 & 4 & Rangifer tarandus & $391 \pm 28$ & $1441-1629$ & -17.70 \\
\hline Beta-308743 & 11 & 3 & Rubus chamaemorus & $400 \pm 30$ & $1436-1625$ & -26.80 \\
\hline SUERC-53010 & 2 & 4 & Rangifer tarandus & $401 \pm 30$ & $1436-1625$ & -18.20 \\
\hline SUERC-53009 & 1 & 4 & Rangifer tarandus & $410 \pm 30$ & $1430-1620$ & -18.90 \\
\hline Beta-308742 & 1 & 4 & Plant material & $570 \pm 30$ & $1304-1423$ & -22.30 \\
\hline
\end{tabular}

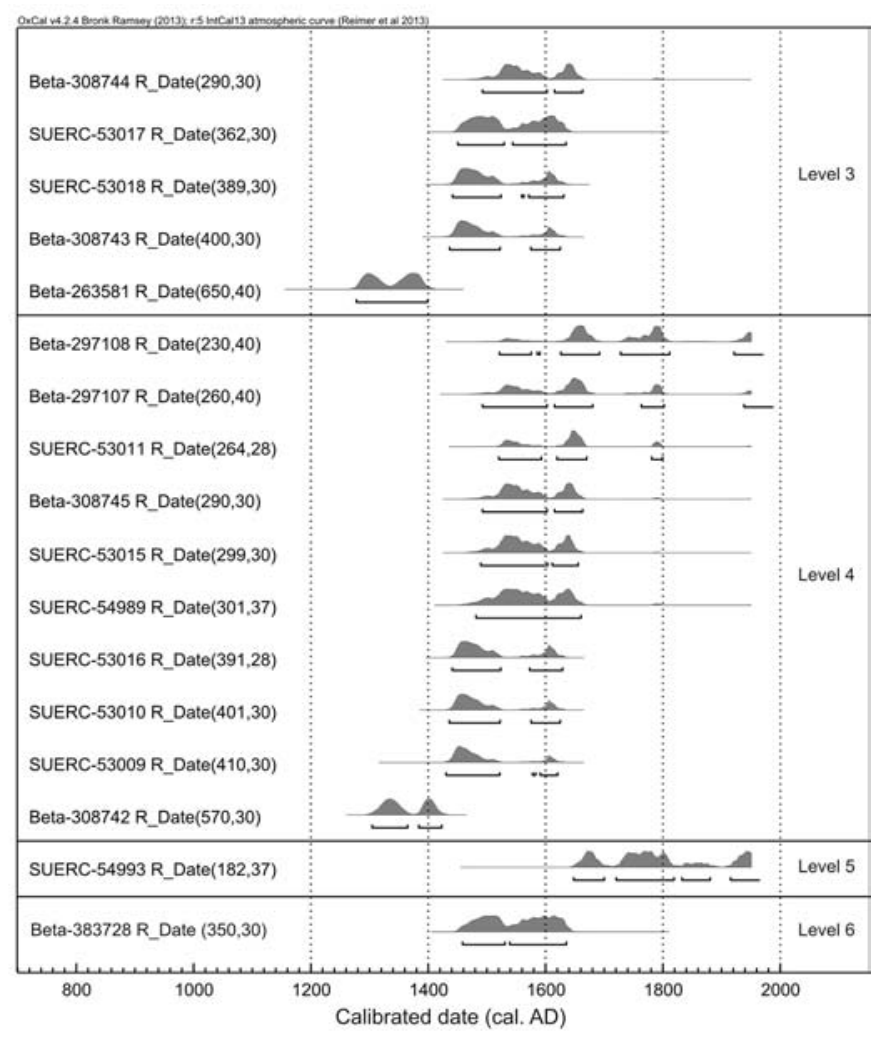

FIG. 2. Rangefinder radiocarbon dates undertaken on materials excavated using planum methods in 2009 to 2012.

oldest of which is yet to be excavated in its entirety. Each is differentiated by episodes of architectural remodeling of the larger sod structure. The occupational deposits are sealed by charred sod and collapsed structural remains that may relate to conflict connected to the Bow and Arrow Wars (Funk, 2010; Fienup-Riordan and Rearden, 2016). Resting above these layers are further sod deposits linked with the long-term collapse of the structure (Figs. 3 and 4).

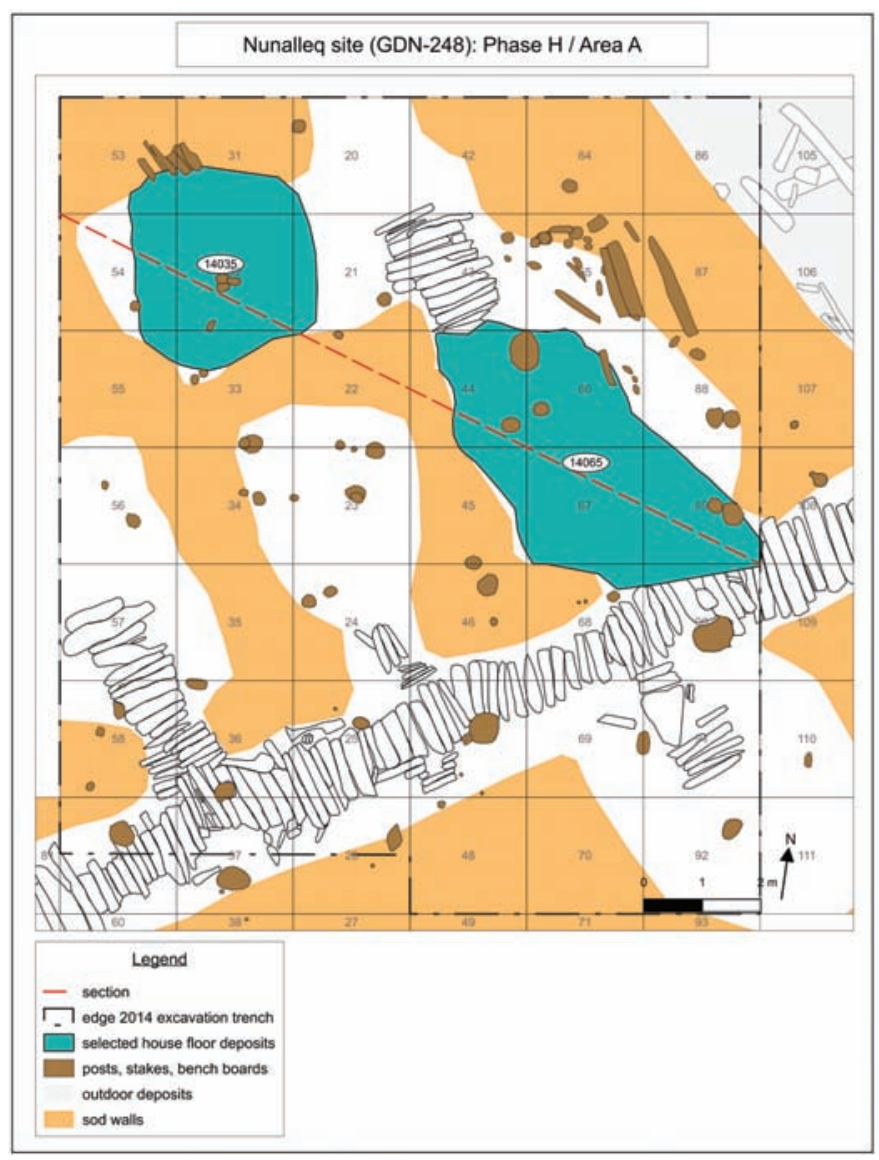

FIG. 3. Schematic site plan indicating the locations of the contexts examined in this study.

\section{METHODS AND MATERIALS}

\section{Excavation and Sampling Methods}

Samples analyzed in this study were collected from archaeological deposits excavated and recorded using the single-context recording system. This system follows the 


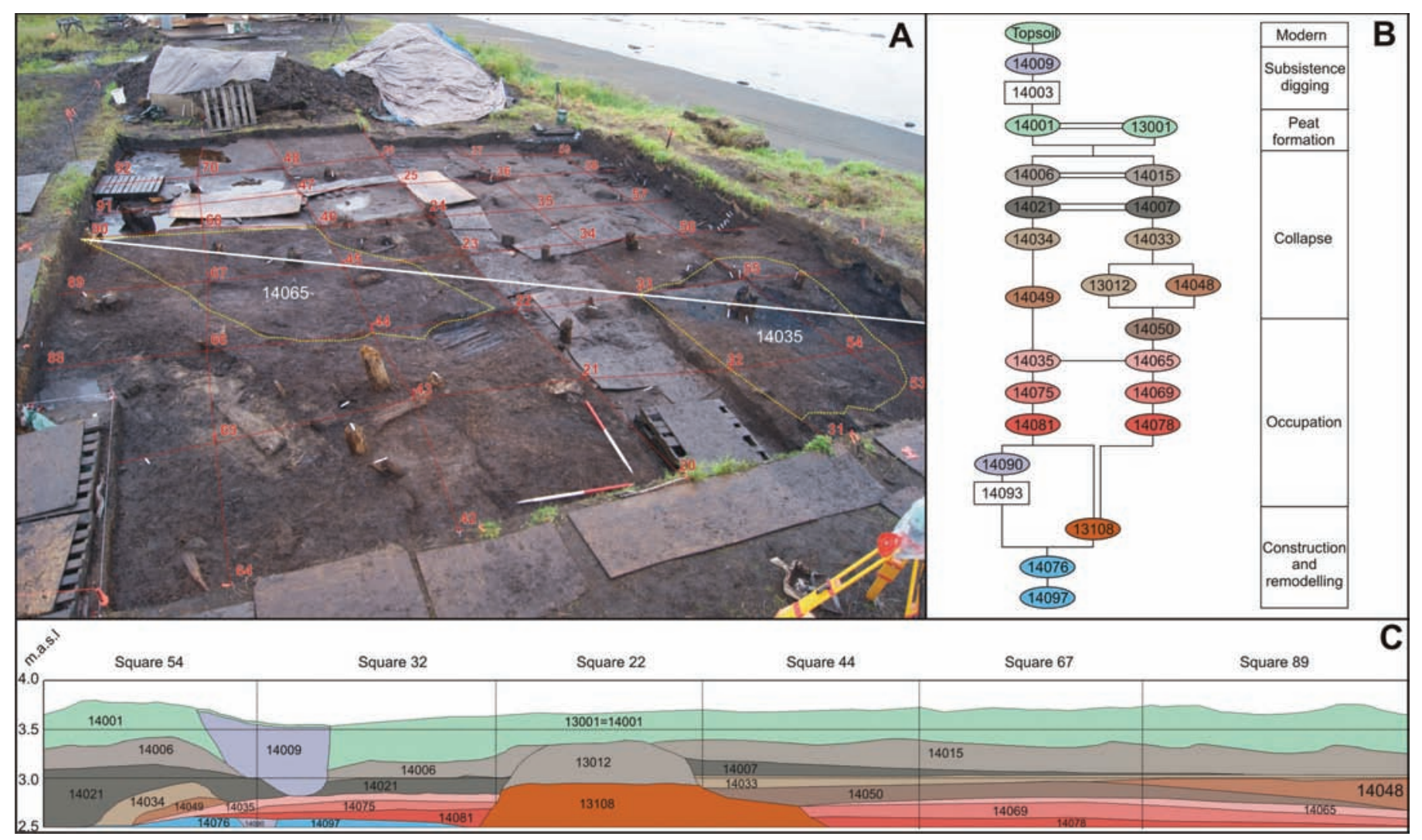

FIG. 4. (A) Photograph (facing southwest) of the excavation at Nunalleq following the removal of debris deposits (contexts 14006, 14015, 14021, 14007, 14034, $14033,13012,14048,14049,14050)$ associated with the collapse of the dwelling. The white line reflects the line of the cross-section presented in C, and the dotted yellow lines illustrate the extent of contexts 14035 and 14065. Grid squares $(2 \times 2 \mathrm{~m})$ and their associated numbers are indicated in red. (B) Partial Harris matrix illustrating the stratigraphic relationships of the deposits intersected by the cross-section presented in C. Ovals represent deposits or fills and squares indicate cut features. Deposits are colour coded: brown $=$ debris, red $=$ house floors, purple $=$ fills, blue $=$ construction or remodeling deposits, and orange $=$ structural deposits. (C) Reconstructed cross-section of the latest phase of activity constructed using the contextual information (including levels and spatial extent) recorded during excavation (c.f. Brown and Harris, 1993).

principle that each stratigraphic unit (defined as a context) is identified, exposed in its entirety, and recorded before being removed (Branch et al., 2005). In practice, this meant that deposits at Nunalleq were excavated in reverse chronological order, with the uppermost (most recent) stratigraphic layer being fully exposed across the excavation grid, assigned a unique context number, recorded (in plan form with measurements of levels), and then sampled and removed to reveal the next deposit. A Harris matrix was constructed to represent the stratigraphic relationships between each excavated context and the next, allowing the establishment of the relative chronologies of all archaeological deposits at the site (Harris, 1979).

Artefact and large animal bone provenance was identified by recording the context number and the grid square in which they were found. In addition, two sets of sampleslarge (2 L) general biological analysis (GBA) and bulk (18 L) faunal samples (Dobney et al., 1992) - were collected from each context, using clean tools, and placed into heavy-gauge plastic bags. In the case of floor layers, GBA samples were taken from each grid square (i.e., multiple samples from single contexts). These were then transported to the University of Aberdeen and stored at $4^{\circ} \mathrm{C}$. Bulk faunal samples were water screened in Quinhagak using a $3 \mathrm{~mm}$ mesh.

\section{Context Selection for This Study}

Two contemporary, although spatially discrete, house floors from the terminal phase of occupation at Nunalleq (contexts 14035 and 14065; Figs. 3; 4A) were selected for study. On the basis of the relationships established through excavation, namely that the floors were buried directly below structural debris and charred sod or wood (Fig. 4B, C), these deposits were interpreted as representing contemporary occupation surfaces. Both contexts were relatively thin, ranging in thickness from 4 to $8 \mathrm{~cm}(14035)$ and 5 to $9 \mathrm{~cm}$ (14065). These deposits represent the terminal levels of a sequence of at least nine distinct house floors of more substantial accumulation, which range in thickness from 8 to $12 \mathrm{~cm}$. A sondage (boring or drilling) in the western portion of the site suggests that a further $40 \mathrm{~cm}$ of deposits remain unexcavated, implying that a further three house floors could underlie the current excavation block. The existing radiocarbon data indicate that the site was occupied for 200-300 years, suggesting that an individual house floor may reflect as little as two decades of deposition.

Both contexts were rich in ecofactual and artefactual remains that could potentially be used for ${ }^{14} \mathrm{C}$ dating. The most common remains were bone (seal, salmonid, dog, 
TABLE 2. Conceptual hierarchy ranking (from top to bottom) the suitability for ${ }^{14} \mathrm{C}$ dating of the organic remains present at Nunalleq in relation to the six criteria outlined in Methods. Green shading indicates that the criterion is no cause for concern and orange indicates potential concern, while red shading indicates a high likelihood that the criterion influenced the ${ }^{14} \mathrm{C}$ measurement. The influence of each criterion as a distorting factor on the ${ }^{14} \mathrm{C}$ determination is ranked in a perceived decreasing order of severity from left to right.

\begin{tabular}{|c|c|c|c|c|c|c|c|}
\hline \multirow[b]{2}{*}{ Single entity } & \multicolumn{5}{|c|}{ Criteria } & \multirow[b]{2}{*}{ Photosynthetic? } & \multirow[b]{2}{*}{ Comments } \\
\hline & $\begin{array}{l}\text { Potential } \\
\text { reservoir } \\
\text { effect? }\end{array}$ & $\begin{array}{l}\text { Potential for } \\
\text { material to } \\
\text { be residual? }\end{array}$ & $\begin{array}{l}\text { Terrestrial } \\
\text { macrofossil? }\end{array}$ & $\begin{array}{l}\text { Potential } \\
\text { for an } \\
\text { inbuilt age? }\end{array}$ & $\begin{array}{l}\text { Short } \\
\text { lived? }\end{array}$ & & \\
\hline $\begin{array}{l}\text { Caribou bone collagen } \\
\text { (Rangifer tarandus) }\end{array}$ & No & No & Yes & No & No & No & \\
\hline $\begin{array}{l}\text { Beetle fossils } \\
\text { (Latridius protensicollis, } \\
\text { Olophrum latum) }\end{array}$ & No & Yes $^{1}$ & Yes & No & Yes & No & $\begin{array}{l}{ }^{1} \text { Insects may derive from peat used } \\
\text { to construct the house. }\end{array}$ \\
\hline $\begin{array}{l}\text { Grass manufactures } \\
\text { (Elymus arenarius) }\end{array}$ & Yes $^{1}$ & $\mathrm{Yes}^{2}$ & Yes & No & Yes & Yes & $\begin{array}{l}{ }^{1} \text { Marine mammal oil effect. } \\
{ }^{2} \text { If object was in use for long periods. }\end{array}$ \\
\hline $\begin{array}{l}\text { Edible berry seeds } \\
\text { (Rubus chamaemorus, } \\
\text { Empetrum nigrum) }\end{array}$ & Yes $^{1}$ & Yes $^{2}$ & Yes & No & Yes & Yes & $\begin{array}{l}{ }^{1} \text { Marine mammal oil effect. } \\
{ }^{2} \text { Seeds may derive from the peat } \\
\text { used to construct the house. }\end{array}$ \\
\hline $\begin{array}{l}\text { Fly puparia } \\
\text { (Heleomyzidae indet.) }\end{array}$ & Yes $^{1}$ & No & Yes & No & Yes & No & $\begin{array}{l}{ }^{1} \text { Potential for flies to have fed on } \\
\text { marine protein. }\end{array}$ \\
\hline $\begin{array}{l}\text { Human lice } \\
\text { (Pediculus humanus) }\end{array}$ & Yes $^{1}$ & No & Yes & No & Yes & No & $\begin{array}{l}{ }^{1} \text { Humans at Nunalleq have a strongly } \\
\text { marine diet. }\end{array}$ \\
\hline $\begin{array}{l}\text { Wood chips } \\
\text { (Picea } \text { sp.) }\end{array}$ & Yes $^{1}$ & Yes & Yes & Yes & No & Yes & ${ }^{1}$ If exposed to marine mammal oil. \\
\hline Charcoal & Yes $^{1}$ & Yes & Yes & Yes & $\mathrm{No}^{2}$ & Yes & $\begin{array}{l}{ }^{1} \text { If exposed to marine mammal oil. } \\
{ }^{2} \text { Depends upon the species. }\end{array}$ \\
\hline Human hair & Yes & No & Yes & Yes & Yes & No & \\
\hline $\begin{array}{l}\text { Fish bone collagen } \\
\text { (Oncorhynchus sp.) }\end{array}$ & Yes & Yes & No & No & No & No & \\
\hline $\begin{array}{l}\text { Seal bone collagen } \\
\text { (Phoca } \mathrm{sp} .)\end{array}$ & Yes & Yes & No & No & No & No & \\
\hline
\end{tabular}

and caribou), seeds (from monocots and edible berries), wood chips, charcoal, insects (fly puparia, lice, and beetles), hair and fur, and grass and wooden artefacts. While many of the ecofacts (such as bone, wood, and charcoal) are frequently preserved on Palaeo- and Neo-Eskimo sites and are commonly used as dating material (e.g., McGhee, 2000; Grønnow and Jensen, 2003), hair, fur, and grass artefacts are extremely rare. More diminutive remains, such as insects and seeds, are probably preserved on many sites and have been recorded in Greenland and the Eastern Arctic (e.g., Zutter, 2009; Dussault et al., 2014; Forbes et al., 2014). However, similar environmental analyses are not routinely conducted in the Western Arctic, and consequently these remains are rarely identified or dated (although see West, 2011).

\section{Radiocarbon Sample Selection for This Study}

Myriad processes influence the ${ }^{14} \mathrm{C}$ age of an ecofact, and clearly not all of the organic remains present at Nunalleq will provide accurate dates (i.e., dates that reflect the true age of the contexts). Six criteria known to influence the accuracy of ${ }^{14} \mathrm{C}$ ages were used to establish a conceptual hierarchy of suitability for the ecofactual remains present at Nunalleq (Table 2). The marine reservoir effect is by far the most serious problem because it has the potential to skew radiocarbon ages of marine organisms by at least 400 ${ }^{14}$ C years (e.g., McGhee and Tuck, 1976; Arundale, 1981; Dumond and Griffin, 2002; Walker, 2005). Samples can be of terrestrial origin, but consumption of marine protein (e.g., Betts, 2008), exposure to marine oils (e.g., Morrison, 1989), ingestion of old carbon in the case of insects (e.g., Hoffecker et al., 2012), or consumption of marine plants may result in ${ }^{14} \mathrm{C}$ ages that do not reflect the assumed isotopic equilibrium with the atmosphere. The potential for a sample to be residual (sensu Bayliss, 2009) is another important factor to consider. For example, curation or reuse of artefacts can result in older materials' being deposited in more recent contexts (e.g., Nelson and McGhee, 2002); 
therefore, it is critical that the material being dated reflect the true age of the context (Morrison, 1989; Gerlach and Mason, 1992). A different problem with similar results will occur if organic materials with an inbuilt age (sensu McFadgen, 1982) are dated, resulting in ${ }^{14} \mathrm{C}$ dates that are centuries older than the deposits from which they were recovered (McGhee, 2009). However, even the selection of short-lived, photosynthetic organisms that should be in isotopic equilibrium with the atmosphere is no guarantee of success, as such samples can be affected by the taphonomic problems discussed above (e.g., West, 2011).

Only remains that were widely distributed across the site (and could therefore be routinely used as dating materials) were selected for dating. Eight different ecofacts were selected for analysis. Both seal (Phoca sp.) and salmonid (Oncorhynchus sp.) bone collagen were chosen to establish the extent of the marine reservoir effect and thus establish a baseline for the posited marine mammal oil effect, while wood chips (Picea sp.), being highly absorbent, were selected to evaluate the presence and severity of this effect. Beetle remains (Coleoptera: Olophrum latum Mäklin and Latridius protensicollis Mann., including multiple elytra, heads, and thoraces from each species) and fly (Diptera: Heleomyzidae) puparia were selected to examine the reliability and practicality of ${ }^{14} \mathrm{C}$ dates on insect remains. The final three ecofacts selected were caribou (Rangifer taran$d u s$ ) bone collagen, grass (Elymus arenarius) manufactures and seeds from two types of edible berries, cloudberry (Rubus chamaemorus) and crowberry (Empetrum nigrum). Notwithstanding the posited marine mammal oil effect, these samples were anticipated, on the basis of previous studies (e.g., McGhee, 2009), to provide the most reliable ages.

\section{Laboratory Methods and Data Analysis}

In total, 16 samples were submitted to the Oxford Radiocarbon Accelerator Unit (ORAU) at the University of Oxford for AMS ${ }^{14} \mathrm{C}$ dating. In all instances, except for caribou bone and grass samples, the ecofacts selected for dating were isolated from GBA samples collected during excavations in 2014. Subsamples of approximately $100 \mathrm{ml}$ of this material were treated with a weak solution of $\mathrm{NaOH}(2 \%-3 \%)$ to disaggregate the sample matrix and then sieved using distilled water. The residues were examined under a binocular microscope, and seeds and wood chips were picked for dating. Beetle and fly remains were obtained after processing one-litre subsamples through flotation (Coope and Osborne, 1967; Kenward et al., 1980). These samples were then placed into distilled water with a drop of $\mathrm{HCl}$ and stored at $4^{\circ} \mathrm{C}$ before being submitted to the ORAU. Grass manufactures and bone were identified in each of the contexts during excavation and cleaned with distilled water before being stored in a dark, dry place. Subsamples were cut from these materials in the Human Palaeoecology Laboratory at the University of Aberdeen before being submitted for dating.
Radiocarbon ages were calibrated using the INTCAL13 calibration curve (Reimer et al., 2013) and a multiplot (Fig. 5) was generated in OxCal (Bronk Ramsey, 2009). If radiocarbon dates on different ecofacts produced overlapping calibrated distributions, their statistical significance was assessed (Fig. 6A) using the Test Sample Significance function in CALIB 7.1 (Stuiver et al., 2016). This method determines a weighted mean of the dates in question and then calculates the test statistic " $T$ " from the weighted sum of the differences between each sample age and weighted mean. The $\mathrm{T}$ value is then compared with a chi-square distribution for $n-1$ samples. If $T$ exceeds the chi-square value, the dates are deemed to be statistically different ages (Ward and Wilson, 1978). In addition to examining intraecofact statistical equivalences, we conducted an intercontext assessment of the consistency of ${ }^{14} \mathrm{C}$ ages of all ecofact types (Fig. 6B) to assess the contemporaneity of the deposits.

\section{RESULTS}

\section{Context 14035}

All of the samples submitted from context 14035 were successfully dated by AMS (Table 3 ). The youngest measurements, as predicted by the conceptual model (Table 2), were returned on $R$. tarandus bone collagen (OxA-32659; $211 \pm 23)$ and E. nigrum seeds (OxA-32646; $259 \pm 25)$, which are statistically indistinguishable at $2 \sigma$ (Fig. 6A). Contrary to the prediction of the conceptual model, the date on E. arenarius (OxA-32958; $382 \pm 30)$ was slightly older than those on seeds and caribou bone (Fig. 5). In fact, the measurement on $E$. arenarius was effectively the same as that on Picea sp. (Fig. 6A) wood chips (OxA-32647; $318 \pm$ 24). The wood chips likely derive from the working of driftwood, so their slight antiquity is unsurprising; however, the statistical equivalence with the date on E. arenarius was not anticipated (Table 2) and indicates that the grass manufacture analyzed may be residual to context 14035 . The dates on insects were also older than expected. Olophrum latum (OxA-X-2672-12; $440 \pm 90)$ returned an age that was statistically indistinguishable from those on wood and grass, while the ${ }^{14} \mathrm{C}$ age of Heleomyzidae puparia (OxA-X2650-27; $791 \pm 29$ ) was intermediate between the oldest and youngest in the context (Fig. 5). The remaining results followed the predictions of the conceptual model. Seal (Phoca sp.) bone collagen provided the oldest age (OxA-32661; $1005 \pm 26$ ), which was slightly older and statistically different from the date on salmonid (Oncorhynchus sp.) bone collagen (OxA-32660; $934 \pm 23)$. This marginally younger ${ }^{14} \mathrm{C}$ age on salmonid bone collagen likely reflects both the anadromous nature and the trophic level of salmon species. Indeed, this hypothesis is borne out in the differences between the stable isotope values of the salmon and seal (Table 4). 


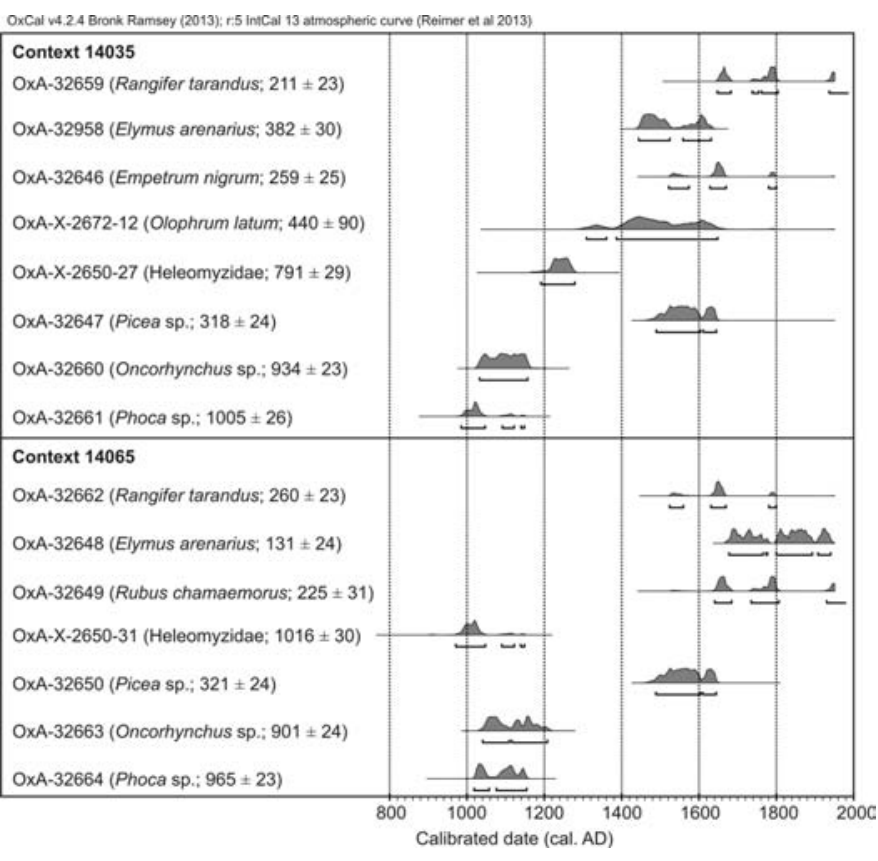

FIG. 5. Calibrated radiocarbon dates of the various ecofacts tested in this study. The multiplot was generated in Oxcal (Bronk Ramsey, 2009).

\section{Context 14065}

Of the eight samples submitted from context 14065, all were successfully dated by AMS except the sample of beetle remains (L. protensicollis), which produced an extremely low carbon yield after pre-treatment. Again, the samples from context 14065 returned results that did not follow the predictions of the conceptual model (Fig. 5). E. arenarius (OxA-32648; $131 \pm 24)$ provided the youngest ${ }^{14} \mathrm{C}$ age, being both younger than and statistically different (at $2 \sigma$ ) from all of the other samples (Fig. 6A). R. chamaemorus seeds (OxA-32649; $225 \pm 31)$ and $R$. tarandus bone collagen (OxA-32662; $260 \pm 23)$ were only marginally older than the date on E. arenarius and returned ${ }^{14} \mathrm{C}$ ages that were indistinguishable from one another (Fig. 6A). As anticipated, the Picea sp. wood chip was slightly older than both caribou bone and cloudberry seeds, which is unsurprising given the absence of trees within the landscape surrounding Nunalleq. The oldest ${ }^{14} \mathrm{C}$ activity in context 14065 , measured on Heleomyzidae (fly) puparia (OxA-X-2650-31; 1016 \pm 30 ), was statistically the same age as the measurement on Phoca sp. bone collagen (OxA-32664; $965 \pm 23$ ). As was the case in context 14035, the measurement on Oncorhynchus sp. (OxA-32663; $901 \pm 24)$ returned a slightly younger ${ }^{14} \mathrm{C}$ activity than that on seal bone, but the dates are statistically equivalent.

\section{DISCUSSION}

A necessary first step in assessing the reliability of ${ }^{14} \mathrm{C}$ measurements is to establish accurately the relative temporal relationships of artefacts and ecofacts from which
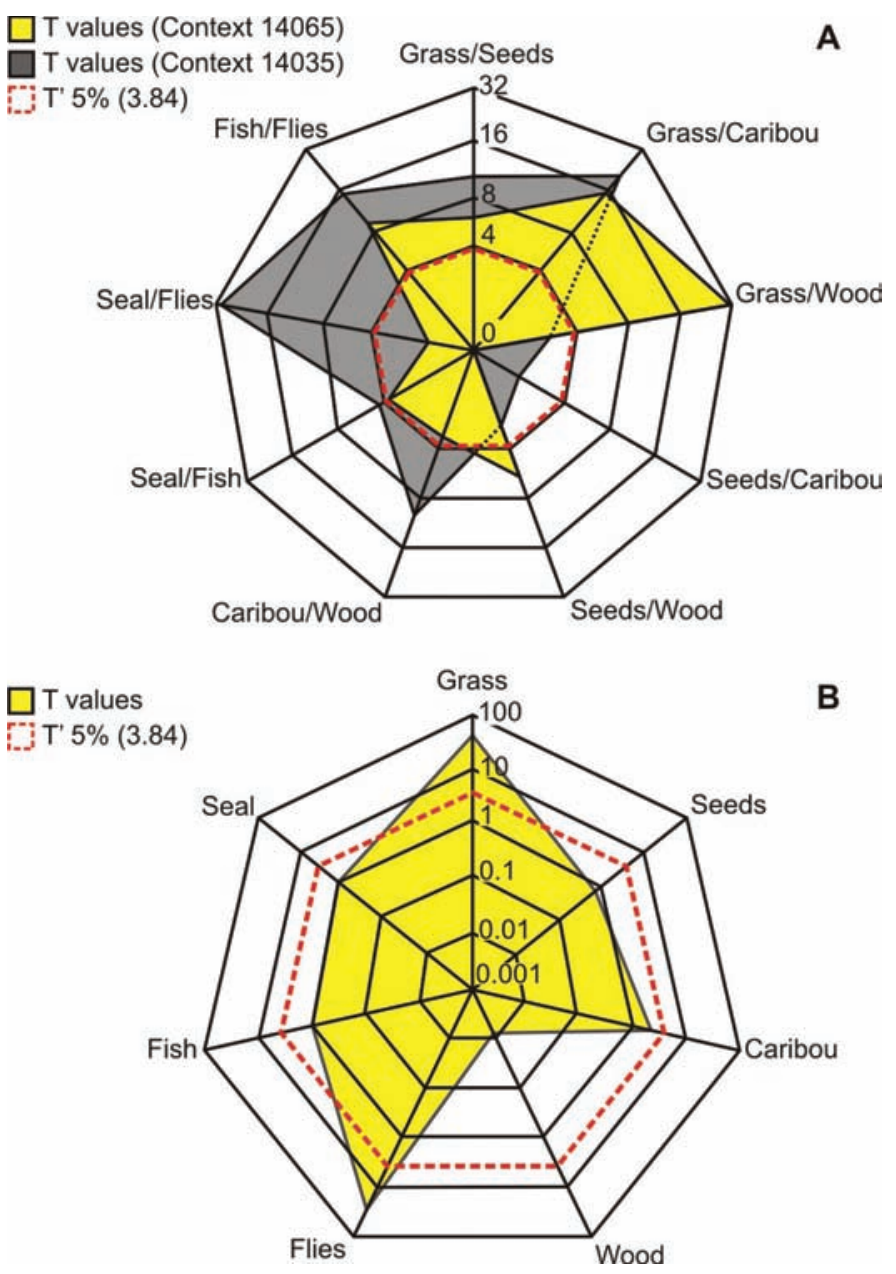

FIG. 6. Measures of dissimilarity between radiocarbon dates calculated in CALIB using the method of Ward and Wilson (1978). (A) Intra-context comparisons of various ecofact combinations. (B) Inter-context comparisons of the same ecofact type. Where T values exceed the T' $5 \%$ value (red dashed line) of 3.84, the two measurements are statistically inconsistent and therefore considered to not represent the same date.

such measurements were obtained. Once a relative chronology is established, it is possible to make assumptions such as: "A was recovered from a deposit located above $\mathrm{B}$; therefore, the ${ }^{14} \mathrm{C}$ age of A will likely post-date that of B." If this assumption is disproved, it is then reasonable to seek a reason why the measurement does not conform to expectations. Accurate recording and precise definition of temporal relationships between deposits during excavation are therefore fundamental to procuring "accurate" radiocarbon dates. To achieve this goal, we used open-area excavation and single-context recording to obtain the samples presented here.

Consequently, the samples from this study derive from contexts with a well-defined temporal association (Fig. 4), and we suggest that these contexts represent contemporary episodes of deposition. In order to test this assumption, we examined the statistical consistency of intra-ecofact ages between the two contexts, the hypothesis being that if the contexts are contemporary, their ${ }^{14} \mathrm{C}$ ages should be statistically indistinguishable. All ecofacts except $E$. arenarius 
386 • P.M. LEDGER et al.

TABLE 3. Radiocarbon dates from this study.

\begin{tabular}{|c|c|c|c|c|c|}
\hline Context & Lab code & Material & ${ }^{14} \mathrm{C}$ yr BP $( \pm 1 \sigma)$ & $\mathrm{AD}( \pm 2 \sigma)$ & $\delta^{13} \mathrm{C}(\% 0)$ \\
\hline \multirow[t]{8}{*}{ 14035: } & OxA-32659 & Rangifer tarandus & $211 \pm 23$ & $1647-1950$ & -17.77 \\
\hline & OxA-2672-12 & Olophorum latum & $440 \pm 90$ & $1310-1648$ & -24.8 \\
\hline & OxA-32958 & Elymus arenarius & $382 \pm 30$ & $1441-1631$ & -29.8 \\
\hline & OxA-32646 & Empetrum nigrum & $259 \pm 25$ & $1522-1800$ & -24.62 \\
\hline & OxA-X-2650-27 & Heleomyzidae indet. & $791 \pm 29$ & $1191-1279$ & -24.2 \\
\hline & OxA-32647 & Picea sp. & $318 \pm 24$ & $1489-1645$ & -24.10 \\
\hline & OxA-32660 & Oncorhynchus sp. & $934 \pm 23$ & $1033-1157$ & -15.35 \\
\hline & OxA-32661 & Phoca sp. & $1005 \pm 26$ & $985-1148$ & -12.17 \\
\hline \multirow[t]{8}{*}{ 14065: } & OxA-32662 & Rangifer tarandus & $260 \pm 23$ & $1524-1799$ & -17.67 \\
\hline & Failed & Latridius protensicollis & NA & NA & NA \\
\hline & OxA-32648 & Elymus arenarius & $131 \pm 24$ & $1677-1940$ & -30.28 \\
\hline & OxA-32649 & Rubus chamaemorus & $225 \pm 31$ & $1640-1950$ & -25.53 \\
\hline & OxA-X-2650-31 & Heleomyzidae indet. & $1016 \pm 30$ & $971-1149$ & -24.2 \\
\hline & OxA-32650 & Picea sp. & $321 \pm 24$ & $1488-1644$ & -23.57 \\
\hline & OxA-32663 & Oncorhynchus sp. & $901 \pm 24$ & $1040-1208$ & -16.22 \\
\hline & OxA-32664 & Phoca sp. & $965 \pm 23$ & $1018-1154$ & -11.26 \\
\hline
\end{tabular}

TABLE 4. Stable isotope values of selected ecofacts.

\begin{tabular}{|c|c|c|c|c|c|c|}
\hline Sample id. & Species & Context & $\delta^{13} \mathrm{C}(\%)$ & $\delta^{15} \mathrm{~N}(\%)$ & $\% \mathrm{C}$ & $\mathrm{C}: \mathrm{N}$ \\
\hline OxA-X-2650-27 & Heleomyzidae indet. & 14035 & -24.20 & 18.70 & 40.30 & 6.70 \\
\hline OxA-X-2650-31 & Heleomyzidae indet. & 14065 & -24.20 & 18.80 & 40.30 & 6.10 \\
\hline OxA-32660 & Oncorhynchus sp. & 14035 & -15.35 & 9.80 & 43.80 & 3.40 \\
\hline OxA-32663 & Oncorhynchus sp. & 14065 & -16.22 & 10.10 & 41.90 & 3.40 \\
\hline OxA-32661 & Phoca sp. & 14035 & -12.17 & 17.50 & 43.90 & 3.40 \\
\hline OxA-32664 & Phoca sp. & 14065 & -11.26 & 21.20 & 46.10 & 3.40 \\
\hline
\end{tabular}

manufactures and Heleomyzidae remains (discussed below) returned statistically indistinguishable ages between contexts. These results demonstrate, within the limits of precision afforded by radiocarbon dating, that the seeds, wood chips, and caribou, seal, and fish bone in each context are the same age, or of statistically indistinguishable age. This result strongly supports the temporal associations of the contexts established through excavation and single-context recording. Therefore, having controlled for stratigraphic complexity as a source of unexpected dating results, we can reasonably seek alternative explanations for the divergent results from flies and grass manufactures. In the case of Heleomyzidae, the different ${ }^{14} \mathrm{C}$ ages may relate to variation within the diet of individual flies, or to differences between species within this fly subfamily. This family comprises species known to breed exclusively on carrion, but also others that breed in mammal and bird excrement or decaying plant matter (Gill and Peterson, 1987; Skidmore, 1995). In context 14065, the age of Heleomyzidae remains was indistinguishable from that of Phoca sp. bone collagen (Fig. 5A), suggesting that perhaps the fossils dated in this instance derive from a species or individuals that fed on seal carrion (cf. Panagiotakopulu et al., 2015). Conversely, the flies dated in context 14035 may have had a different diet, although the stable isotope values (Table 3 ) are equivocal.

The factors behind the divergent results from artefacts constructed of $E$. arenarius are less clear, as grass was anticipated to be reliable dating material (e.g., Dumond and Griffin, 2002). In context 14065, E. arenarius returned a ${ }^{14} \mathrm{C}$ age that was younger than and statistically different from all other ecofacts in the context (Fig. 5, 6). A plausible interpretation could be that $E$. arenarius reflects the true age of context 14065 and that the dates on $R$. chamaemorus and $R$. tarandus are in fact residual. Although tempting, this scenario seems unlikely given the consistency in the two contexts of all of the other measurements (Fig. 6B) and the reliability of dates of caribou bone collagen elsewhere in the Arctic (e.g., Friesen and Arnold, 2008; McGhee, 2000, 2009). More reasonably (given the overlapping calibrated distributions), the divergent dates may reflect the broad plateau associated with the radiocarbon calibration curve, which limits dating precision from the mid-16th century onwards (Burr, 2013), or with measurement uncertainty (Scott, 2013). Alternatively, it is possible that the sample of $E$. arenarius submitted for dating was contaminated in some way with modern carbon during post-excavation processing, which would have resulted in a younger age (Taylor and Bar-Yosef, 2014). For example, small fragments of more recent plant material could feasibly have become lodged within the weave of the grass manufacture, which would then have influenced the final age of the sample when it was measured in the laboratory. The results from context 14035 present the opposite situation, with $E$. arenarius being equivalent in age to wood chips of Picea sp. and older than both E. nigrum and $R$. tarandus. In this instance it would appear that the grass manufacture is residual to the context (sensu Bayliss, 2009). Grass manufactures are typically assumed to have relatively short lifespans of usage, on the order of one to five years. However, this result suggests this may not always be the case. 
An alternative possibility is that this slightly older datec. $120-170{ }^{14} \mathrm{C}$ years older than those on E. nigrum and $R$. tarandus - is evidence for the marine mammal oil effect cited by a number of researchers (e.g., Park, 1994; Anderson and Freeburg, 2013).

Dumond and Griffin (2002) have suggested that the marine reservoir effect in the Bering Sea is on the order of $450-750{ }^{14} \mathrm{C}$ years. This age range is consistent with the dates on seal in this study. In context 14035 , the date on seal bone collagen is between 746 and $794{ }^{14} \mathrm{C}$ years older than the respective dates on E. nigrum and $R$. tarandus, while in context 14065, the respective differences between seal and $R$. tarandus and R. chamaemorus are 705 and $740{ }^{14} \mathrm{C}$ years (Table 2). If the slightly older age on E. arenarius were a result of contamination with marine mammal oils, a much greater ${ }^{14} \mathrm{C}$ age difference would seem likely. Furthermore, the consistency of the ${ }^{14} \mathrm{C}$ ages of ecofacts between contexts (Figs. 5, 6) and of caribou bone collagen and seed dates, and the absence of unusually old dates on wood, which would presumably be susceptible to the marine mammal oil effect, provide no evidence for this effect at Nunalleq.

In light of the measurements presented here, a reappraisal of the conceptual hierarchy (Table 2) proposed at the outset is necessary. Caribou bone collagen was originally hypothesized to be the most suitable material for dating (c.f. McGhee, 2000; Friesen, 2009), wood was expected to be residual (c.f. Appelt and Gulløv, 2009), and seal and fish bone were anticipated to be the least suitable (c.f. Dumond and Griffin, 2002). The results of this study do not alter these assessments. The main changes relate to recommendations for dating seeds and grass manufactures. As a short-lived terrestrial species, E. arenarius was originally thought likely to be a highly suitable dating material (Table 2). In fact, however, dates on E. arenarius were inconsistent. In context 14065 , grass manufactures returned the youngest ${ }^{14} \mathrm{C}$ age of the study, while in context 14035 , their date was older than expected. The first of these results suggests that grass manufactures may be susceptible to contamination, while the second indicates that although E. arenarius is short-lived, the artefacts constructed from it may have longer use periods than previously assumed. As for seeds, those from edible berries are abundant in the archaeological remains of sod structures since they are part of the fabric of the peat blocks used to construct such dwellings. Consequently, the potential for seeds of edible berries to be residual to archaeological contexts was judged to be high, and they were ranked less suitable for dating than caribou bone collagen. However, the consistency of the ${ }^{14} \mathrm{C}$ ages on seeds between the two contexts, and between caribou, crowberry, and cloudberry within the same context (Fig. 6A and B), provides no evidence for the seeds used for this study having been residual. Therefore, on the basis of this evidence, edible berry seeds can be said to be as reliable as caribou bone collagen as a dating material.

\section{CONCLUSIONS}

Recent decades have witnessed a gradual reassessment and greater appreciation of the complexities of radiocarbon data by archaeologists working in the North American Arctic. Few researchers continue to procure ${ }^{14} \mathrm{C}$ dates on sea mammal bones and wooden artefacts, and there is a growing acceptance that terrestrial macrofossils are the key to accurate radiocarbon chronologies. Despite these advances, problems remain. For instance, there is often only cursory recognition that accurate relative chronology (for sites and dating materials) is essential if radiocarbon data from the Arctic, and their inherent taphonomic issues, are to be fully understood. Indeed, despite frequent calls, there has been little engagement with assessing the respective ${ }^{14} \mathrm{C}$ dating suitability of different organic remains.

This study addressed both of these issues. Using openarea excavation and single-context recording, we ensured a robust interpretation of the temporal relationships of the materials analyzed. Statistical equivalence of intraecofact ${ }^{14} \mathrm{C}$ measurements between the two contexts confirmed these measurements and provided us with greater confidence that further ${ }^{14} \mathrm{C}$ age variation was related to taphonomy and not stratigraphy. These results demonstrate that caribou bone collagen is a reliable and accurate dating material, but more importantly, they indicate that seeds from edible berries (Rubus chamaemorus and Empetrum nigrum) also produce reliable dates that are statistically indistinguishable from those on caribou. Contrary to expectations, grass manufactures were unreliable, returning different ages in the two contexts. In context 14065 , they were younger than caribou bone and seeds, while in context 14035, they were older. Measurements on other materials either confirmed well-established trends or followed expectations.

Despite the successes of this study, it is important to recognize its limitations. Only two contexts were analyzed, and to draw more statistically significant conclusions, a larger dataset covering more contexts, but testing fewer ecofact types (i.e., seeds, caribou bone, seal bone, wood, and grass) would be appropriate. An example would be demonstrating statistical equivalence of ${ }^{14} \mathrm{C}$ dates on seeds and caribou across several stratigraphically contemporary archaeological contexts. Furthermore, it is essential to stress the applicability of these findings. The ecofacts dated in this study derive from clearly delineated house floors, and therefore they could reasonably be assumed to have been deposited during the formation of these archaeological layers. Although ecofacts such as seeds are likely to be abundant in archaeological deposits from the Arctic, there is little value dating seeds of uncertain provenance. Such an ecofact could easily derive from the peat used to construct the dwelling and would therefore not be dating the archaeological event of interest.

Context, in the sense of understanding the relative relationship between archaeological deposits, is therefore the key to improved dating. Our own experiences at 
Nunalleq, where we transitioned from planum to singlecontext recording, support this. The original suite of dates, on material sourced from multiple squares, provided a coarse estimate for the duration of occupation at the site, but with some inconsistencies and a limited means for assessing the reliability of these measurements. In contrast, single-context recording has provided a relative chronology for all of the archaeological deposits at Nunalleq, while also conferring confidence in the results of this study. Going forward with this robust relative chronology, it will be possible to use Bayesian statistics to construct highly resolved (sub-centennial) archaeological datasets to tackle questions pertaining to dietary and technological change, shifting subsistence patterns, and responses to subcentennial climatic variation.

\section{ACKNOWLEDGEMENTS}

The results presented in this paper were funded by a NERC Radiocarbon Facility grant (NRCF 1917.0415), while the wider project is funded by the Arts and Humanities Research Council (AH/K006029/1). The authors wish to thank all the members of the excavation crew from the 2014 field season for their hard work in the challenging weather conditions of Southwest Alaska. Without their attention to detail, this study would not have been possible. Additional thanks are also due to Qanirtuuq Incorporated for logistical support and warm hospitality in Quinhagak. We also wish to thank Kevin Edwards and Kate Britton, who read an earlier draft of this paper, and three anonymous reviewers for highly constructive criticism that helped us to improve the final manuscript.

\section{REFERENCES}

Alaska Center for Conservation Science. 2016. Vegetation map for Northern, Western, and Interior Alaska. Anchorage: University of Alaska, Anchorage.

http://accs.uaa.alaska.edu/vegetation-ecology/vegetation-mapnorthern-western-and-interior-alaska/

Anderson, S.L., and Freeburg, A.K. 2013. A high-resolution chronology for the Cape Krusenstern site complex, Northwest Alaska. Arctic Anthropology 50(1):49-71.

http://dx.doi.org/10.3368/aa.50.1.49

Anstey, R.J., Guiry, E.J., Renouf, M.A.P., Deal, M., and Fuller, B.T. 2016. Dating archaeobotanical remains: A cautionary tale from Port au Choix, Newfoundland. Vegetation History and Archaeobotany 25(1):75-84. http://dx.doi.org/10.1007/s00334-015-0526-y

Appelt, M., and Gullov, H.C. 2009. Tunit, Norsemen, and Inuit in thirteenth-century Northwest Greenland: Dorset between the devil and the deep sea. In: Maschner, H., Mason, O., and McGhee, R., eds. The northern world, AD 900-1400. Salt Lake City: University of Utah Press. 300-320.
Arundale, W. 1981. Radiocarbon dating in Eastern Arctic archaeology: A flexible approach. American Antiquity 46(2):244-271.

http://dx.doi.org/10.2307/280207

Bayliss, A. 2009. Rolling out revolution: Using radiocarbon dating in archaeology. Radiocarbon 51(1):123-147. http://dx.doi.org/10.2458/azu_js_rc.51.3483

Betts, M.W. 2008. Subsistence and culture in the Western Canadian Arctic: A multicontextual approach. Mercury Series, Archaeology Paper 169. Hull, Quebec: Canadian Museum of Civilization.

Branch, N., Canti, M., Clark, P., and Turney, C. 2005. Environmental archaeology: Theoretical and practical approaches. London: Hodder Arnold.

Britton, K., Knecht, R., Nehlich, O., Hillerdal, C., Davis, R.S., and Richards, M.P. 2013. Maritime adaptations and dietary variation in prehistoric Western Alaska: Stable isotope analysis of permafrost-preserved human hair. American Journal of Physical Anthropology 151(3):448-461. http://dx.doi.org/10.1002/ajpa.22284

Britton, K., McManus-Fry, E., Nehlich, O., Richards, M., Ledger, P.M., and Knecht, R. In press. Stable carbon, nitrogen and sulphur isotope analysis of permafrost preserved human hair from rescue excavations $(2009,2010)$ at the precontact site of Nunalleq, Alaska. Journal of Archaeological Science: Reports. Available online 10 June 2016.

http://dx.doi.org/10.1016/j.jasrep.2016.04.015

Bronk Ramsey, C. 2009. Bayesian analysis of radiocarbon dates. Radiocarbon 51(1):337-360.

http://dx.doi.org/10.2458/azu_js_rc.51.3494

Brown, M.R., III, and Harris, E.C. 1993. Interfaces in archaeological stratigraphy. In: Harris, E.C., Brown M.R., and Brown, G.J., eds. Practices of archaeological stratigraphy. London: Academic Press. 7-20. http:/dx.doi.org/10.1016/B978-0-12-326445-9.50006-X

Burr, G.S. 2013. Radiocarbon dating: Causes of temporal ${ }^{14} \mathrm{C}$ variations. In: Elias, S.A., ed. Encyclopedia of Quaternary science, 2nd ed. London: Elsevier. 336-334. http://dx.doi.org/10.1016/B978-0-444-53643-3.00046-7

Coope, G.R., and Osborne, P.J. 1967. Report on the coleopterous fauna of the Roman well at Barnsley Park, Gloucestershire. Transactions of the Bristol and Gloucestershire Archaeological Society 86:84-87.

Dobney, K., Hall, K.R., Kenward, H.K., and Milles, A. 1992. A working classification of sample types for environmental archaeology. Circaea 9(1):24-26.

Dumond, D.E. 1987. The Eskimos and Aleuts, 2nd ed. London: Thames and Hudson Ltd.

Dumond, D.E., and Griffin, D.G. 2002. Measurements of the marine reservoir effect on radiocarbon ages in the eastern Bering Sea. Arctic 55(1):77-86. http://dx.doi.org/10.14430/arctic692

Dussault, F., Bain, A., and LeMoine, G. 2014. Early Thule winter houses: An archaeoentomological assessment. Arctic Anthropology 51(1):101 - 117.

http://dx.doi.org/10.3368/aa.51.1.101 
Fienup-Riordan, A., and Rearden, A. 2016. Anguyiim Nalliini/ Time of warring: The history of bow-and-arrow warfare in Southwest Alaska. Anchorage: University of Alaska Press.

Forbes, V., Dussault, F., and Bain, A. 2014. Archaeoentomological research in the North Atlantic: Past, present, and future. Journal of the North Atlantic 26:1-24.

Forbes, V., Britton, K., and Knecht, R. 2015. Preliminary archaeoentomological analyses of permafrost-preserved cultural layers from the pre-contact Yup'ik Eskimo site of Nunalleq, Alaska: Implications, potential and methodological considerations. Environmental Archaeology 20(2):158-167. http://dx.doi.org/10.1179/1749631414Y.0000000037

Friesen, T.M. 2009. The last supper: Late Dorset economic change at Iqaluktuuq, Victoria Island. In: Maschner, H., Mason, O., and McGhee, R., eds. The northern world, AD 900-1400. Salt Lake City: University of Utah Press. 235-248.

Friesen, T.M., and Arnold, C.D. 2008. The timing of the Thule migration: New dates from the western Canadian Arctic. American Antiquity 73(3):527-538.

Funk, C. 2010. The bow and arrow war days on the YukonKuskokwim delta of Alaska. Ethnohistory 57(4):523 -569. http://dx.doi.org/10.1215/00141801-2010-036

Gerlach, C., and Mason, O.K. 1992. Calibrated radiocarbon dates and cultural interaction in the Western Arctic. Arctic Anthropology 29(1):54-81.

Giddings, J.L. 1967. Ancient men of the Arctic. Seattle: University of Washington Press.

Gill, G.D., and Peterson, B.V. 1987. Heleomyzidae. In: McAlpine, J.F., Peterson, B.V., Shewell, G.E., Teskey, H.J., Vockeroth, J.R., and Wood, D.M., eds. Manual of Nearctic Diptera, Vol. 2. Agriculture Canada Monograph 28. Ottawa: Minister of Supply and Services Canada. 973-980.

Grønnow, B., and Jensen, J.F. 2003. The northernmost ruins of the globe: Eigil Knuth's archaeological investigations in Peary Land and adjacent areas of High Arctic Greenland. Meddelelser om Grønland, Man \& Society 29. 403 p.

Gulløv, H.C. 1997. From Middle Ages to colonial times: Archaeological and ethnohistorical studies of the Thule culture in south west Greenland 1300-1800 AD. Meddelelser om Grønland, Man \& Society 23. 494 p.

Harris, E.C. 1979. Principles of archaeological stratigraphy. London: Academic Press.

Hodgetts, L.M., Eastaugh, E., and Munizzi, J. 2015. The Ikaahuk Archaeology Project: Report on the 2014 field season. London, Ontario: The University of Western Ontario.

Hoffecker, J.F., Mason, O.K., Elias, S.A., Hanson, D.K., Alix, C., Reynolds, G.L., and Leeper, K. 2012. Uivvaq: A stratified Iñupiaq occupation at Cape Lisburne, Northwest Alaska. Alaska Journal of Anthropology 10(1-2):143-172.

Jensen, A.M. 2006. Radiocarbon dates from recent excavations at Nuvuk, Point Barrow, Alaska and their implications for Neoeskimo prehistory. In: Grønnow, B. ed. On the track of the Thule culture from Bering Strait to East Greenland. Proceedings of the SILA conference 'The Thule culture new perspectives in Inuit prehistory,' Copenhagen, October 26th-28th, 2006. Papers in honour of Hans Christian Gulløv. Copenhagen: Publications of the National Museum Studies in Archaeology and History Vol 15. 45-62.
Jensen, J.F. 2006. The Stone Age of Qeqertarsup Tunua (Disko Bugt): A regional analysis of the Saqqaq and Dorset cultures of central West Greenland. Meddelelser om Grønland, Man \& Society $32.72 \mathrm{p}$.

Kenward, H.K., Hall, A.R., and Jones, A.K.G. 1980. A tested set of techniques for the extraction of plant and animal macrofossils from waterlogged archaeological deposits. Science and Archaeology 22:3-15.

Knecht, R.A., and Jordan, R.H. 1985. Nunakakhnak: A Historic Period Koniag village in Karluk, Kodiak Island, Alaska. Arctic Anthropology 22(2):17-35.

Mann, D.H., Heiser, P.A., and Finney, B.P. 2002. Holocene history of the Great Kobuk Sand Dunes, northwestern Alaska. Quaternary Science Reviews 21(4-6):709-731.

http://dx.doi.org/10.1016/S0277-3791(01)00120-2

McFadgen, B.G. 1982. Dating New Zealand archaeology by radiocarbon. New Zealand Journal of Science 25:379-392.

McGhee, R. 1996. Ancient people of the Arctic. Vancouver: UBC Press.

. 2000. Radiocarbon dating and the timing of the Thule migration. In: Appelt, M., Berglund, J., and Gulløv, H.C., eds. Identities and cultural contacts in the Arctic. Proceedings from a conference at the Danish National Musuem, Copenhagen, 30 November to 2 December 1999. Copenhagen: Danish Polar Centre. $181-191$.

2009. When and why did the Inuit move to the eastern Arctic? In: Maschner, H., Mason, O., and McGhee, R., eds. The northern world, AD 900-1400. Salt Lake City: University of Utah Press. 155-163.

McGhee, R., and Tuck, J.A. 1976. Un-dating the Canadian Arctic. In: Maxwell, M.S., ed. Eastern Arctic prehistory: Palaeoeskimo problems. Memoirs of the Society for American Archaeology No. 31. 6-14.

Morrison, D. 1989. Radiocarbon dating Thule culture. Arctic Anthropology 26(2):48-77.

Nelson, D.E., and McGhee, R. 2002. Aberrant radiocarbon dates on an Inuit arrowhead. Arctic 55(4):345-347.

http://dx.doi.org/10.14430/arctic718

Oswald, W.W., Anderson, P.M., Brown, T.A., Brubaker, L.B., Hu, F.S., Lozhkin, A.V., Tinner, W., and Kaltenrieder, P. 2005. Effects of sample mass and macrofossil type on radiocarbon dating of Arctic and boreal lake sediments. The Holocene 15(5):758-767. http://dx.doi.org/10.1191/0959683605h1849rr

Panagiotakopulu, E., Higham T.F.G., Buckland, P.C., Tripp, J.A., and Hedges, R.E.M. 2015. AMS dating of insect chitin - A discussion of new dates, problems and potential. Quaternary Geochronology 27:22-32. http://dx.doi.org/10.1016/j.quageo.2014.12.001

Park, R.W. 1994. Approaches to dating the Thule culture in the Eastern Arctic. Canadian Journal of Archaeology 18:29-48.

Ramsden, P., and Rankin, L.K. 2013. Thule radiocarbon chronology and its implications for early Inuit-European interaction in Labrador. In: Pope, P.E., and Lewis-Simpson, S., eds. Exploring Atlantic transitions: Archaeologies of transience and permanence in new found lands. The Society for PostMedieval Archaeology Monograph 8. London: Boydell Press. 299-309. 
Reimer, P.J., Bard, E., Bayliss, A., Beck, J.W., Blackwell, P.G., Bronk Ramsey, C., Buck, C.E., et al. 2013. IntCal 13 and Marine13 radiocarbon age calibration curves, $0-50,000$ years cal BP. Radiocarbon 55(4):1869-1887. http://dx.doi.org/10.2458/azu_js_rc.55.16947

Renfrew, C., and Bahn, P. 2004. Archaeology: Theories, methods and practice, 4th ed. London: Thames \& Hudson.

Savelle, J.M., and Habu, J. 2004. A processual investigation of a Thule whale bone house, Somerset Island, Arctic Canada. Arctic Anthropology 41(2):204-221. http://dx.doi.org/10.1353/arc.2011.0033

Schledermann, P., and McCullough, K. 1980. Western elements in the early Thule culture of the eastern High Arctic. Arctic 33(4):833-841. http://dx.doi.org/10.14430/arctic2599

Scott, E.M. 2013. Radiocarbon dating: Sources of error. In: Elias, S.A., ed. Encyclopedia of Quaternary science, 2nd ed. London: Elsevier. 324-328. http://dx.doi.org/10.1016/B978-0-444-53643-3.00050-9

Skidmore, P. 1995. A dipterological perspective on the Holocene history of the North Atlantic area. PhD thesis, University of Sheffield, United Kingdom.

Stuiver, M., Reimer, P.J., and Reimer, R. 2016. CALIB radiocarbon calibration, version 7.1.

http:/calib.qub.ac.uk/calib/
Sutherland, P.D. 2009. The question of contact between Dorset Paleo-Eskimos and early Europeans in the Eastern Arctic. In: Maschner, H., Mason, O., and McGhee, R., eds. The northern world, AD 900-1400. Salt Lake City: University of Utah Press. 279-299.

Taylor, R.E., and Bar-Yosef, O. 2014. Radiocarbon dating: An archaeological perspective, 2nd ed. Walnut Creek, California: Left Coast Press.

Walker, M. 2005. Quaternary dating methods. London: John Wiley \& Sons Ltd.

Ward, G.K., and Wilson, S.R. 1978. Procedures for comparing and combining radiocarbon age determinations: A critique. Archaeometry 20(1):19-31. http://dx.doi.org/10.1111/j.1475-4754.1978.tb00208.x

West, C.F. 2011. A revised radiocarbon sequence for Karluk-1 and the implications for Kodiak Island prehistory. Arctic Anthropology 48(1):80-92. http://dx.doi.org/10.1353/arc.2011.0111

Woollett, J.M., Henshaw, A.S., and Wake, C.P. 2000. Palaeoecological implications of archaeological seal bone assemblages: Case studies from Labrador and Baffin Island. Arctic 53(4):395-413. http://dx.doi.org/10.14430/arctic870

Zutter, C. 2009. Palaeoethnobotanical contributions to 18thcentury Inuit economy: An example from Uviak, Labrador. Journal of the North Atlantic, Special Volume 1:23-32. 